\title{
Nitrogen and phosphorus cycling in the digestive system and shell biofilm of the eastern oyster Crassostrea virginica
}

\author{
Nicholas E. Ray ${ }^{1, *}$, Maria C. Henning ${ }^{2}$, Robinson W. Fulweiler ${ }^{1,2}$ \\ ${ }^{1}$ Boston University, Department of Biology, Boston, MA 02215, USA \\ ${ }^{2}$ Department of Earth and Environment, Boston University, Boston, MA 02215, USA
}

\begin{abstract}
The shell and digestive system of bivalves provide microhabitats for an array of microbes that can mediate biogeochemical cycles. Here, we investigated nitrogen $(\mathrm{N})$ and phosphorus (P) fluxes in these microhabitats in the eastern oyster Crassostrea virginica. From the anoxic oyster digestive system, we measured significant production of dinitrogen gas $\left(\mathrm{N}_{2}-\mathrm{N}_{\text {; }}\right.$ mean \pm SE: $0.59 \pm 0.20 \mu \mathrm{mol}$ ind..$\left.^{-1} \mathrm{~h}^{-1}\right)$ and nitrous oxide $\left(\mathrm{N}_{2} \mathrm{O} ; 0.001 \pm 0.0004 \mu \mathrm{mol}\right.$ ind..$\left.^{-1} \mathrm{~h}^{-1}\right)$, indicative of denitrification. The oxic shell biofilm released $\mathrm{N}_{2} \mathrm{O}\left(0.0003 \pm 0.0001 \mu \mathrm{mol}\right.$ ind $\left.^{-1} \mathrm{~h}^{-1}\right)$, as well as ammonium $\left(\mathrm{NH}_{4}{ }^{+} ; 1.26 \pm 0.20 \mu \mathrm{mol}\right.$ ind. $\left.{ }^{-1} \mathrm{~h}^{-1}\right)$ and nitrite $\left(\mathrm{NO}_{2}^{-} ; 0.05 \pm 0.01 \mu \mathrm{mol}\right.$ ind. ${ }^{-1}$ $\mathrm{h}^{-1}$ ), but not $\mathrm{N}_{2}-\mathrm{N}$, suggesting a combination of nitrification and heterotrophic activity. The biofilm released more dissolved inorganic $\mathrm{P}$ than the digestive system, although the rate of release from whole oysters was closer to the rate from the digestive system alone. $\mathrm{N}$ remineralized by oysters is released almost exclusively as $\mathrm{NH}_{4}{ }^{+}$, at a ratio of 18.4:1 with P, i.e. relatively close to the Redfield ratio (16:1). In an ecological context, this study supports the growing literature on the ability of oysters themselves to engage in denitrification activity and at rates potentially exceeding rates of sediment denitrification. The denitrification in the digestive system appears to proceed to completion and has a very small $\mathrm{N}_{2} \mathrm{O}$ cost $(<1 \%)$. Restoring oyster populations may therefore be an important method for $\mathrm{N}$ reduction in coastal systems.
\end{abstract}

KEY WORDS: Oyster $\cdot$ Nitrogen $\cdot$ Denitrification $\cdot$ Nitrous oxide $\cdot$ Nitrification $\cdot$ Shellfish

\section{INTRODUCTION}

Oysters provide a suite of ecosystem services, including habitat provision and regulation of coastal nitrogen (N) cycling processes (Coen et al. 2007). At an ecosystem scale, oyster reefs and aquaculture provide habitat for a range of higher trophic level organisms such as fish and invertebrates (Peterson et al. 2003), as well as microbial communities (Nocker et al. 2004). At an individual scale, the oyster itself is host to a diverse microbiome in both its digestive system and the biofilm that lives on its shell (King et al. 2012, Arfken et al. 2017). Oysters regulate N cycling at the ecosystem scale by transporting suspended particulates to the sediment during filter-feeding

${ }^{*}$ Corresponding author: nray@bu.edu
(Newell et al. 2005) and at the individual scale through digestion processes and provision of habitat for biofilms (Wahl et al. 2012, Lacoste \& GaertnerMazouni 2015). Oysters are naturally evolved to live in dense populations, so while the magnitude of $\mathrm{N}$ cycling processes occurring in the digestive system and in the shell biofilm of individual oysters may seem insignificant, regulation of $\mathrm{N}$-cycling by large oyster populations could have important impacts at the ecosystem scale.

The 2 microhabitats in oysters differ greatly in microenvironmental conditions and thus support communities with different life strategies: the digestive system is a low-oxygen and low-light environment, while the shell is exposed to oxygen and light

() The authors 2019. Open Access under Creative Commons by Attribution Licence. Use, distribution and reproduction are unrestricted. Authors and original publication must be credited. 
during the day. The bivalve shell biofilm hosts microbes that can oxidize ammonium $\left(\mathrm{NH}_{4}{ }^{+}\right)$to create nitrate $\left(\mathrm{NO}_{3}{ }^{-}\right)$through nitrification (Welsh \& Castadelli 2004, Caffrey et al. 2016) and also provides substrate for epiphytes including suspensionfeeders, algae, and single-cell primary producers (Lacoste \& Gaertner-Mazouni 2015) that can excrete or assimilate $\mathrm{NH}_{4}{ }^{+}$. For the rest of this paper, we use the term 'biofilm' to collectively describe the whole shell community. The oyster digestive system likely functions similarly as in other bivalves, supporting denitrification (the reduction of $\mathrm{NO}_{3}{ }^{-}$to dinitrogen $\left[\mathrm{N}_{2}\right]$ gas) and thus potentially provides the ecosystem service of reducing the biologically available $\mathrm{N}$ load in coastal ecosystems (Stief 2013).

The contrasting oxygen availabilities and associated N-cycling processes occurring in each oyster microhabitat potentially create a feedback loop, as different $\mathrm{N}$-cycling processes are spatially and functionally coupled in oysters. The shell nitrifier community is 'fertilized' by $\mathrm{NH}_{4}{ }^{+}$excreted by the bivalve (Heisterkamp et al. 2013), and the $\mathrm{NO}_{3}{ }^{-}$created during nitrification can be transported into the bivalve as it feeds, providing resources for denitrifiers living in the digestive system. In marine and aquatic systems, release of nitrous oxide $\left(\mathrm{N}_{2} \mathrm{O}\right)$, a greenhouse gas with 298 times the global warming potential of carbon dioxide (Myhre et al. 2013), is positively correlated with the concentration of $\mathrm{NH}_{4}{ }^{+}$and $\mathrm{NO}_{3}{ }^{-}$in the water column (Seitzinger \& Nixon 1985, Beaulieu et al. 2011). Consequently, excretion of $\mathrm{NH}_{4}{ }^{+}$by the oyster digestive system could drive $\mathrm{N}_{2} \mathrm{O}$ production by the shell biofilm (Heisterkamp et al. 2013, Erler et al. 2017), and the $\mathrm{NO}_{3}{ }^{-}$produced by the biofilm could drive $\mathrm{N}_{2} \mathrm{O}$ production in the digestive system (Stief et al. 2009, Heisterkamp et al. 2010, Svenningsen et al. 2012, Welsh et al. 2015, Bonaglia et al. 2017).

In addition to $\mathrm{N}$, the eastern oyster Crassostrea virginica is known to influence estuarine phosphorus (P) cycling by excreting phosphate $\left(\mathrm{PO}_{4}{ }^{3-}\right)$ (Satomi \& Pomeroy 1965). The contribution of the digestive system and shell biofilm to $\mathrm{PO}_{4}{ }^{3-}$ release from the whole oyster remains unclear, although we hypothesize that the majority of $\mathrm{PO}_{4}^{3-}$ release will be from the oyster digestive system, as $\mathrm{PO}_{4}{ }^{3-}$ is created during the digestion of organic material such as phytoplankton. The amount of $\mathrm{P}$ released relative to $\mathrm{N}$ is important when considering which nutrient limits phytoplankton growth in coastal systems.

The magnitude of nitrification and denitrification in bivalves occurs at rates that are ecologically significant (Welsh \& Castadelli 2004, Stief et al. 2009) and can proceed at rates higher than in the surrounding sediment (Smyth et al. 2013, Arfken et al. 2017). Large oyster reefs were once dominant features of coastal ecosystems (Beck et al. 2011, Zu Ermgassen et al. 2012), and declines in oyster populations due to overharvesting and disease have altered how many coastal ecosystems function (Newell 1988). Today, oyster populations are increasing in some areas as a result of reef restoration and aquaculture development, highlighting the importance of understanding how these microhabitats interact and regulate $\mathrm{N}$ biogeochemistry in coastal systems. While native oyster species are being restored in some ecosystems, nonnative species have been introduced to others. Understanding how different oyster and bivalve species regulate nutrient recycling and removal in coastal ecosystems - and the mechanisms by which they do so - is an important step toward making sound decisions regarding species introductions.

In this study, we measured net fluxes of dissolved inorganic $\mathrm{N}$ and $\mathrm{P}, \mathrm{N}_{2}$, and $\mathrm{N}_{2} \mathrm{O}$ from whole oysters, whole oysters with the shell biofilm removed, and oyster shells with an intact biofilm. These treatments allowed us to measure rates of $\mathrm{N}$ and $\mathrm{P}$ cycling processes in the oyster digestive system, the shell biofilm community, and how the $\mathrm{N}$ and $\mathrm{P}$ cycling processes in these 2 microhabitats interact. We hypothesized that denitrification would occur primarily in the oyster digestive system and nitrification would mainly occur in the shell biofilm. We also hypothesized that rates of denitrification and nitrification would be higher in whole oysters due to the coupling of $\mathrm{N}$ cycling processes occurring in each microhabitat. Denitrification was measured as net release of $\mathrm{N}_{2}-\mathrm{N}$ and $\mathrm{N}_{2} \mathrm{O}$ from the oyster digestive system. Nitrification was inferred as release of $\mathrm{N}_{2} \mathrm{O}$ and $\mathrm{NO}_{3}{ }^{-}$and consumption of $\mathrm{NH}_{4}{ }^{+}$by the shell biofilm. Interaction between the 2 microhabitats would be demonstrated by higher rates of $\mathrm{N}_{2}-\mathrm{N}$ efflux and lower rates of $\mathrm{NH}_{4}{ }^{+}$release from whole oysters relative to the digestive system alone.

\section{MATERIALS AND METHODS}

\subsection{Oyster collection and characterization}

Market-size eastern oysters Crassostrea virginica were purchased from East Beach Farm in Ninigret Pond, Rhode Island, USA, on 3 occasions in the summer of 2015 (23 July, 4 August, and 12 August). Ninigret Pond is a shallow coastal lagoon which is separated from Block Island Sound by a barrier spit. Water exchanges with Block Island Sound through a 
small breachway that is occasionally dredged, with a residence time of approximately $10 \mathrm{~d}$. Multiple oyster farms operate in the lagoon, and efforts to build restored reefs are underway. A HOBO dissolved oxygen (DO) data logger deployed adjacent to the oyster farm recorded mean temperatures of (mean \pm SE) $25.2 \pm 0.0^{\circ} \mathrm{C}$ with a range in temperature of $21.2-30.1^{\circ} \mathrm{C}$ over the course of the experiment. The site experiences strong diurnal cycles in DO concentration, ranging from $3.9 \pm 2.7 \mathrm{mg} \mathrm{l}^{-1}$ to $15.0 \pm 4.0 \mathrm{mg}$ $\mathrm{l}^{-1}$ during the course of our study. Mean salinity was $30.6 \pm 0.8$ in July and $30.7 \pm 0.3$ in August.

We brought the oysters to Boston University in a cooler with site water, where they were moved to an environmental chamber set to $24.0^{\circ} \mathrm{C}$, i.e. the water temperature at the oyster farm when we collected oysters for the first incubation. We used the same temperature for all 3 incubations in order to eliminate any temperature-associated variation in fluxes. The oysters were kept overnight in aerated site water, and incubations to measure gas fluxes were conducted the following day. Prior to treating the oysters and beginning the incubations, we weighed them and measured the length, width, and depth of their shell. We then labeled each oyster by loosely wrapping it with a rubber band with a waterproof tape tag. Each incubation included 36 oysters. Following each incubation, we shucked the oysters, dried the tissue at $60.0^{\circ} \mathrm{C}$, and recorded the dry tissue mass once the weight changed less than $1 \%$ over a period of $24 \mathrm{~h}$.

\subsection{Oyster treatments}

We measured fluxes from whole oysters, the shell biofilm, and whole oysters with the shell biofilm removed. The role of the shell biofilm was isolated by carefully shucking oysters, removing the animal tissue, and then putting the shells back together (Erler et al. 2017). We inferred microbial activity in the digestive system using whole oysters with the shell biofilm removed. Any processes occurring in the mantle cavity are also captured in our shell biofilm treatment.

We removed the shell biofilm using a combined chemical and mechanical approach presented by Tamburri et al. (1992) that is quick, minimally invasive, and removes all of the external biofilm. First, the oysters were vigorously scrubbed with a soft plastic bristle brush for $3 \mathrm{~min}$, then rinsed 3 times, and soaked in artificial sea water (ASW) with a salinity of 31 for $5 \mathrm{~min}$. Next, the oysters were bathed in a $2.5 \%$ household bleach solution for 5 min. Following this bath, the oysters were again rinsed 3 times with ASW and then kept in ASW until the start of the incubation (at least $2 \mathrm{~h}$ ). All oysters were closed during the course of chemical and mechanical biofilm removal, and we visually ensured all oysters were open and pumping following the biofilm removal before beginning the incubation. We also tested the ASW in which the oysters were soaked following the bleach treatment and the chambers they were incubated in for the presence of chlorine using a Hach Model CN$66 \mathrm{~T}$ chlorine test kit. In all cases, there was no chlorine present in the water.

\subsection{Incubation procedure}

We filled gas-tight chambers $(28 \mathrm{~cm}$ long clear PVC tubes, $10 \mathrm{~cm}$ diameter, total volume $2.15 \mathrm{l}$ ) with unfiltered site water that had been bubbled overnight, and then added 4 whole oysters, scrubbed oysters, pairs of shells, or water only (as control) depending on the treatment. Each treatment was replicated in triplicate, for a total of 12 chambers per incubation (3 replicates of each of the 4 treatments). The cores were capped with gas-tight acrylic lids with an inflow port connected to a $20 \mathrm{l}$ carboy of site water, an outflow port from which samples were collected, and a magnetic stir bar to keep water in the chamber gently mixed ( 40 revolutions $\mathrm{min}^{-1}$; Foster \& Fulweiler 2016).

Water samples for analysis of DO, dissolved inorganic $\mathrm{N}\left(\mathrm{NH}_{4}{ }^{+}, \mathrm{NO}_{3}{ }^{-}, \mathrm{NO}_{2}{ }^{-}\right)$, and dissolved inorganic $\mathrm{P}\left(\mathrm{PO}_{4}{ }^{3-}\right)$ concentrations were collected at the beginning and end of the experiment. DO was measured using an optical sensor (LDO101; Hach). Inorganic nutrient samples were filtered through a Whatman GF/F filter ( 0.7 micron) into 2 acid-washed polyethylene bottles, which were immediately frozen until analysis.

We collected duplicate water samples for $\mathrm{N}_{2}-\mathrm{N}$ and $\mathrm{N}_{2} \mathrm{O}$ concentrations at 5 time points during the incubation. At each of the 5 time points, we filled $12 \mathrm{ml}$ glass exetainers $(\mathrm{Labco} \mathrm{n}=4)$ from the bottom with sample water, allowing the exetainer to overflow 3 times (Foster \& Fulweiler 2016). We then added $25 \mu \mathrm{l}$ of saturated zinc chloride solution to preserve the sample prior to capping the exetainer with a gastight cap. During sample collection, both the inflow and outflow ports were opened so that water from the carboy would replace the collected sample water. At all times throughout the incubations, there were no bubbles or headspace in any of the chambers (Foster \& Fulweiler 2016). Sample time points for dissolved 
gas analysis were spaced to allow for at least a $2.0 \mathrm{mg}$ $\mathrm{l}^{-1}$ drop in DO in the chamber water between the first and last sample while maintaining DO concentration above the hypoxic threshold of $2.0 \mathrm{mg} \mathrm{l}^{-1}$ (Foster \& Fulweiler 2016). Incubations ranged from $2-3.5 \mathrm{~h}$.

Accounting for gas sample collection and occasional DO checks, replacement of water within the chambers was less than $15 \%$ throughout the course of the incubation. Lights in the environmental chamber were left on during the course of the incubation.

\subsection{Sample analysis}

Dissolved nutrient samples were analyzed using high-resolution digital colorimetry on a SEAL Autoanalyzer 3 with standard techniques (SEAL methods G171-96 for $\mathrm{NH}_{4}{ }^{+}, \mathrm{G} 173-96$ for $\mathrm{NO}_{2}{ }^{-}, \mathrm{G} 172-96$ for $\mathrm{NO}_{\mathrm{x}}$ and G175-96 for $\mathrm{PO}_{4}{ }^{3-}$ ). The detection limits during these analyses were $0.08 \mu \mathrm{M} \mathrm{NH}_{4}{ }^{+}, 0.013 \mu \mathrm{M}$ $\mathrm{NO}_{\mathrm{x}}\left(\mathrm{NO}_{2}{ }^{-}+\mathrm{NO}_{3}{ }^{-}\right), 0.006 \mu \mathrm{M} \mathrm{NO}{ }^{-}$, and $0.01 \mu \mathrm{M}$ $\mathrm{PO}_{4}{ }^{3-}$. $\mathrm{NO}_{3}{ }^{-}$concentrations were calculated as $\left[\mathrm{NO}_{\mathrm{x}}\right]$ - $\left[\mathrm{NO}_{2}{ }^{-}\right]$. In cases where $\left[\mathrm{NO}_{2}{ }^{-}\right]$was greater than $\left[\mathrm{NO}_{\mathrm{x}}\right]$, we considered $\left[\mathrm{NO}_{3}{ }^{-}\right]$to equal 0 . We used the following equation to estimate fluxes of DO and dissolved nutrients:

$$
\text { Flux }=\frac{[]_{\text {final }}-[]_{\text {initial }} \times \text { Volume }}{\text { Time } \times \text { Number of oysters }}
$$

For dissolved nutrients, the initial and final concentrations were the average value of the 2 replicate samples collected at each time point.

We determined $\mathrm{N}_{2}-\mathrm{N}$ concentrations using a quadrupole membrane inlet mass spectrometer (MIMS) according to the $\mathrm{N}_{2} / \mathrm{Ar}$ method (Kana et al. 1994). This method has a high precision $\left( \pm 0.03 \% \mathrm{~N}_{2} / \mathrm{Ar}\right)$, and $\mathrm{N}_{2}$ concentration is estimated by multiplying the $\mathrm{N}_{2} / \mathrm{Ar}$ ratio of the sample determined by MIMS by the theoretical Ar concentration of the sample given its temperature and salinity in order to estimate the sample $\mathrm{N}_{2}-\mathrm{N}$ concentration (Weiss 1970, Colt 1984). While there is some potential for oxygen in the water samples to influence $\mathrm{N}_{2}$ measurements on the MIMS, this interference is small and within the range of precision of the instrument (Kana \& Weiss 2004).

Concentrations of dissolved $\mathrm{N}_{2} \mathrm{O}$ were measured using a headspace equilibration technique followed by analysis on a gas chromatograph (GC; Foster \& Fulweiler 2016). A gas headspace in the sample exetainer was created by simultaneously adding $5 \mathrm{ml}$ of ultra-high purity helium and removing $5 \mathrm{ml}$ of water sample through the septa, using gas-tight glass syringes. Following creation of the headspace, vials were shaken vigorously for $10 \mathrm{~s}$ and left upright to equilibrate for at least $1 \mathrm{~h}$. After equilibration, $4 \mathrm{ml}$ of sample head-space were removed and injected into a Shimadzu 2014 GC equipped with an electron capture detector with ${ }^{63} \mathrm{Ni}$ source for analysis of $\mathrm{N}_{2} \mathrm{O}$. The GC columns were packed with HayeSep ${ }^{\circledR}$ and Shimalite ${ }^{\circledR}$. We used $\mathrm{N}_{2}$ gas as the carrier gas and P5 ( $5 \% \mathrm{CH}_{4}$ and $95 \% \mathrm{Ar}$ ) as the electron capture detector make-up gas. We estimated the concentration of $\mathrm{N}_{2} \mathrm{O}$ in our samples by comparing the area under the peaks generated for our samples against a standard curve of peak areas of different concentrations of an externally mixed standard made up of $500 \mathrm{ppb} \mathrm{N}_{2} \mathrm{O}$ in $\mathrm{N}_{2}$ (Airgas). All standard curves had $\mathrm{R}^{2} \geq 0.995$ for the 6 time points. The detection limit for $\mathrm{N}_{2} \mathrm{O}$ during sample analysis was $0.386 \mu \mathrm{M}$.

Flux rates for $\mathrm{N}_{2}-\mathrm{N}$ and $\mathrm{N}_{2} \mathrm{O}$ in each incubation chamber were estimated by first calculating the rate of change in concentration of the gas over time using a linear regression and then calculating a gas flux rate per oyster using the slope calculated in the regression analysis. We only considered fluxes to be significant when $\mathrm{R}^{2} \geq 0.65$ and $\mathrm{p} \leq 0.10$ (Prairie 1996, Foster \& Fulweiler 2014, 2016). When the fluxes did not meet these criteria, we considered there to be no change in gas concentration over time, and thus the flux was 0 . All fluxes measured in this study were linear. Finally, to remove the effect of any gas flux occurring in the water used during the incubations, we subtracted the average flux of the 3 water-only chambers from the individual treatment chambers from that incubation (Table S1 in the Supplement at www. int-res.com/articles/suppl/m621p095_supp.pdf).

\subsection{Statistical analyses}

We used R statistical software v. 3.3.2 (R Core Team 2014) to perform all statistical analyses and considered the results of all statistical tests to be significant when $p \leq 0.05$. We compared the physical characteristics (whole oyster wet weight, shell length, shell width, and shell height) of oysters used in different incubations, between treatments pooled among incubations using Kruskal-Wallis tests, followed by Dunn's test when the Kruskal-Wallis test was significant.

The flux data generated in this study were of a relatively small sample size ( $\mathrm{n}=9$ for each treatment), were not normally distributed, and there were differences in starting water chemistry, so we used a nonparametric statistical approach. We tested whether fluxes of dissolved gases and nutrients for each treatment (whole oyster, shell biofilm only, digestive sys- 
Table 1. Whole oyster weight and shell size dimensions of eastern oysters used in the 3 incubations (mean $\pm \mathrm{SE}$ ) in 2015. Within a column, different letters indicate significant differences $(\mathrm{p} \leq 0.05)$ in the weight or size metric between incubations using a Kruskal-Wallis test and Dunn post hoc analysis

\begin{tabular}{|lllll|}
\hline Incubation date & Wet weight $(\mathrm{g})$ & Length $(\mathrm{cm})$ & Width $(\mathrm{cm})$ & Height $(\mathrm{cm})$ \\
\hline 24 July & $44.90 \pm 1.47^{\mathrm{a}}$ & $7.66 \pm 0.14^{\mathrm{a}}$ & $4.81 \pm 0.10^{\mathrm{a}}$ & $1.90 \pm 0.04^{\mathrm{a}}$ \\
5 August & $47.10 \pm 1.41^{\mathrm{a}}$ & $7.68 \pm 0.10^{\mathrm{a}}$ & $5.03 \pm 0.15^{\mathrm{b}}$ & $1.62 \pm 0.04^{\mathrm{b}}$ \\
13 August & $50.92 \pm 1.41^{\mathrm{b}}$ & $7.21 \pm 0.13^{\mathrm{b}}$ & $5.16 \pm 0.10^{\mathrm{b}}$ & $2.06 \pm 0.06^{\mathrm{c}}$ \\
\hline
\end{tabular}

\subsection{Comparison of fluxes from the shell biofilm and digestive system}

The oyster digestive system and shell biofilm both consumed significant quantities of $\mathrm{O}_{2}$ (Table 2). $\mathrm{O}_{2}$ consumption in whole oysters $(12.36$ $\pm 1.48 \mu \mathrm{mol}$ ind. $^{-1} \mathrm{~h}^{-1}$ ) was nearly twice the sum of consumption in the 2 microhabitats (Fig. 1).

tem only) were significantly greater than 0 (or less than 0 for $\mathrm{O}_{2}$ fluxes) by pooling fluxes from the 3 incubations and using a 1-sample Wilcoxon signed rank test. We compared fluxes between the 3 treatments using a Kruskal-Wallis test followed by Dunn's test if the Kruskal-Wallis test was significant.

\section{RESULTS}

\subsection{Oyster sizes and incubation conditions}

The mean \pm SE whole oyster wet weight in the 3 incubations was $47.67 \pm 0.85 \mathrm{~g}$. The oysters had a shell length of $7.51 \pm 0.07 \mathrm{~cm}$, shell width of $5.00 \pm$ $0.07 \mathrm{~cm}$, and shell height of $1.86 \pm 0.03 \mathrm{~cm}$. Oysters purchased for the third incubation were heavier than those used for the first 2 incubations, as well as slightly shorter in length, wider, and with a deeper cup (Table 1). Despite differences in the sizes of oysters purchased on different dates, oyster wet weight $(\mathrm{p}=0.65)$, shell length $(\mathrm{p}=0.56)$, shell width $(\mathrm{p}=$ $0.28)$, and shell height $(p=0.84)$ were not different between treatments when the 3 incubations were pooled. The average dry tissue mass of oysters used in this study was $2.93 \pm 0.05 \mathrm{~g}$. Starting dissolved inorganic $\mathrm{N}$ and $\mathrm{P}$ concentrations were similar between incubations, although starting concentrations of $\mathrm{NH}_{4}{ }^{+}$and $\mathrm{PO}_{4}{ }^{3-}$ were slightly higher during the second of the 3 incubations (Table S2).
Fluxes of dissolved nutrients were generally higher from the shell biofilm than the oyster digestive system, significantly so for $\mathrm{NH}_{4}{ }^{+}, \mathrm{NO}_{2}{ }^{-}$, and $\mathrm{PO}_{4}{ }^{3-}$ (Fig. 2). Compared to the digestive system, the shell

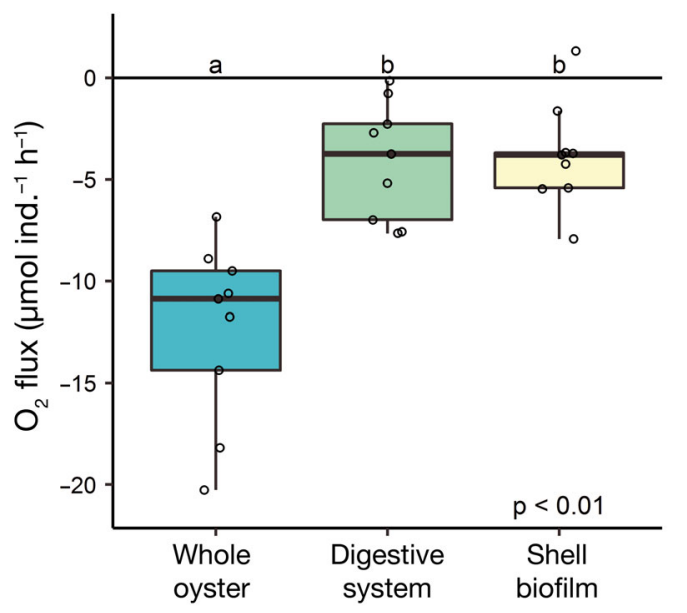

Fig. 1. Fluxes of $\mathrm{O}_{2}$ from whole eastern oysters, the oyster dimiddle of each box is the median, the lower and upper edges of the boxes indicate the 25th and 75th percentiles, and the end of each whisker indicates the smallest and largest value within 1.5 times the interquartile range. Each point represents an individual flux measurement. p-values show the result of Kruskal-Wallis tests comparing treatments, with different letters indicating groups that are significantly different following pairwise comparison. Points below the 0 line show net consumption, while points above 0 indicate net production gestive system, and the shell biofilm. The solid line in the

Table 2. Fluxes from whole eastern oysters, their digestive system, and their shell biofilm. All values indicate mean ( \pm SE). pvalues in parentheses indicate whether the flux was significantly different from 0 following a 1-sample Wilcoxon test. Significant values $(\mathrm{p} \leq 0.05)$ are in bold. All fluxes are in $\mu \mathrm{mol}$ ind.$^{-1} \mathrm{~h}^{-1}$

\begin{tabular}{|c|c|c|c|c|c|c|c|}
\hline Treatment & $\mathrm{O}_{2}$ flux & $\mathrm{NH}_{4}{ }^{+}$flux & $\mathrm{NO}_{3}^{-}$flux & $\mathrm{NO}_{2}^{-}$flux & $\mathrm{PO}_{4}{ }^{3-}$ flux & $\mathrm{N}_{2}-\mathrm{N}$ flux & $\mathrm{N}_{2} \mathrm{O}$ flux \\
\hline Whole oyster & $\begin{array}{c}-12.36 \pm 1.48 \\
\mathbf{( 0 . 0 0 2 )}\end{array}$ & $\begin{array}{c}1.42 \pm 0.27 \\
(\mathbf{0 . 0 0 2 )}\end{array}$ & $\begin{array}{c}0.80 \pm 1.46 \\
(0.752)\end{array}$ & $\begin{array}{c}0.05 \pm 0.02 \\
(\mathbf{0 . 0 0 2 )}\end{array}$ & $\begin{array}{c}0.08 \pm 0.02 \\
(\mathbf{0 . 0 0 2 )}\end{array}$ & $\begin{array}{c}0.41 \pm 0.22 \\
(\mathbf{0 . 0 4 9 )}\end{array}$ & $\begin{array}{c}0.0004 \pm 0.0001 \\
(\mathbf{0 . 0 0 5 )}\end{array}$ \\
\hline Digestive system & $\begin{array}{c}-4.11 \pm 0.96 \\
(\mathbf{0 . 0 0 2 )}\end{array}$ & $\begin{array}{c}0.62 \pm 0.17 \\
(\mathbf{0 . 0 0 6 )}\end{array}$ & $\begin{array}{c}0.03 \pm 0.19 \\
(0.410)\end{array}$ & $\begin{array}{c}0.01 \pm 0.00 \\
\quad(\mathbf{0 . 0 0 4 )}\end{array}$ & $\begin{array}{c}0.05 \pm 0.02 \\
(\mathbf{0 . 0 0 6 )}\end{array}$ & $\begin{array}{c}0.59 \pm 0.20 \\
(\mathbf{0 . 0 1 4 )}\end{array}$ & $\begin{array}{l}0.001 \pm 0.0004 \\
\quad(\mathbf{0 . 0 0 7 )}\end{array}$ \\
\hline Shell biofilm & $\begin{array}{c}-3.84 \pm 0.86 \\
(\mathbf{0 . 0 0 4 )}\end{array}$ & $\begin{array}{c}1.26 \pm 0.20 \\
(\mathbf{0 . 0 0 2 )}\end{array}$ & $\begin{array}{c}2.17 \pm 1.55 \\
(0.285)\end{array}$ & $\begin{array}{c}0.05 \pm 0.01 \\
(\mathbf{0 . 0 0 2 )}\end{array}$ & $\begin{array}{c}0.46 \pm 0.12 \\
\quad(\mathbf{0 . 0 0 2 )}\end{array}$ & $\begin{array}{c}0.00 \pm 0.17 \\
(0.500)\end{array}$ & $\begin{array}{c}0.0003 \pm 0.0001 \\
(\mathbf{0 . 0 1 0 )}\end{array}$ \\
\hline
\end{tabular}



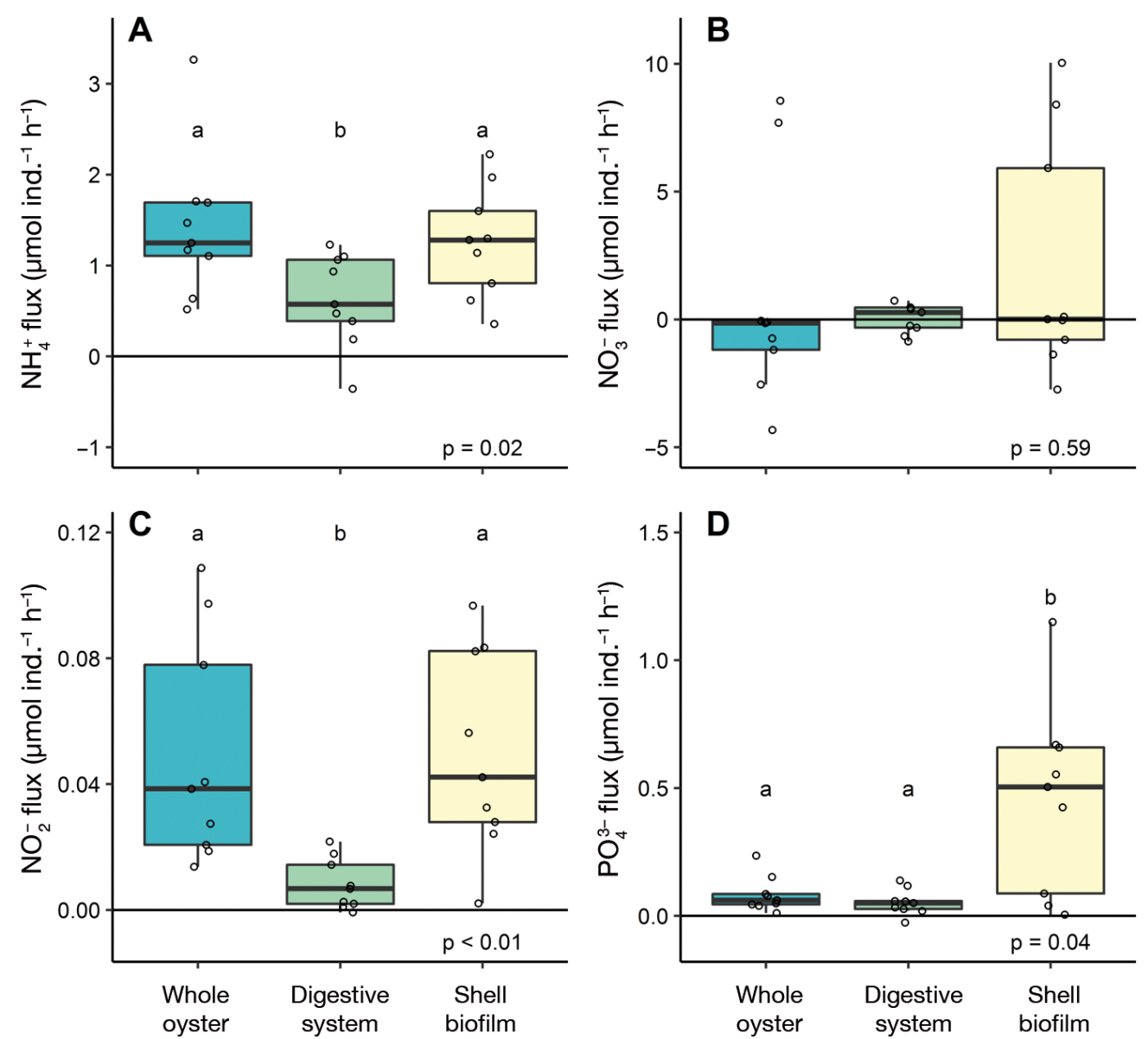

Fig. 2. Fluxes of (A), $\mathrm{NH}_{4}{ }^{+}$, (B) $\mathrm{NO}_{3}{ }^{-}$, (C) $\mathrm{NO}_{2}{ }^{-}$, and (D) $\mathrm{PO}_{4}{ }^{3-}$ from whole oysters, the oyster digestive system, and the shell biofilm. Other details as in Fig. 1

biofilm released twice as much $\mathrm{NH}_{4}{ }^{+}, 5$ times as much $\mathrm{NO}_{2}{ }^{-}$, and 9 times as much $\mathrm{PO}_{4}{ }^{3-}$ (Table 2). We did not record significant fluxes of $\mathrm{NO}_{3}{ }^{-}$for any treatment.

There was no statistical difference in $\mathrm{N}_{2}-\mathrm{N}$ production between the digestive system and the shell biofilm ( $\mathrm{p}=0.12$; Fig. 3 ). However, $\mathrm{N}_{2}-\mathrm{N}$ fluxes from the shell biofilm were not significantly different from 0 , while the digestive system released $\mathrm{N}_{2}-\mathrm{N}$ at a rate of $0.59 \pm 0.20 \mu \mathrm{mol}$ ind. ${ }^{-1} \mathrm{~h}^{-1}$, approximately equal to the rate of $\mathrm{N}_{2}-\mathrm{N}$ production for whole oysters $\left(0.41 \pm 0.22 \mu \mathrm{mol}\right.$ ind. ${ }^{-1} \mathrm{~h}^{-1}$; Table 2$) . \mathrm{N}_{2} \mathrm{O}$ was released by both the shell biofilm $(0.0003 \pm 0.0001$ umol ind. $\left.{ }^{-1} \mathrm{~h}^{-1}\right)$ and digestive system $(0.0010 \pm$ $0.0004 \mu \mathrm{mol}$ ind..$\left.^{-1} \mathrm{~h}^{-1}\right)$, although the rate of release from whole oysters $\left(0.0004 \pm 0.0001 \mu \mathrm{mol}\right.$ ind..$\left.^{-1} \mathrm{~h}^{-1}\right)$ was not different from the 2 microhabitats (Fig. 3).

We found no significant differences when fluxes for each treatment were compared between incubation dates.

\section{DISCUSSION}

\section{1. $\mathrm{N}$ and $\mathrm{P}$ cycling processes in the oyster digestive system and shell biofilm}

We recorded net release of $\mathrm{N}_{2}-\mathrm{N}$ and $\mathrm{N}_{2} \mathrm{O}$ from scrubbed oysters and measured no flux of $\mathrm{N}_{2}-\mathrm{N}$ from the shell biofilm, indicating that all denitrification occurred in the oyster digestive system. Despite differences in methods, our measured rate of denitrification in whole oysters is comparable, albeit at the lower end of rates reported in other studies (Table 3). Unlike our study, which recorded no denitrification in the oyster shell biofilm, both Caffrey et al. (2016) and Arfken et al. (2017) recorded significant denitrification in empty oyster shells, although the contribution of the oyster shell to whole oyster denitrification varied from 27.5 to $97.5 \%$ between the studies. This variance is likely due to differences in the biofilm community inhabiting the oyster shell in different estuaries, or methodologi- 

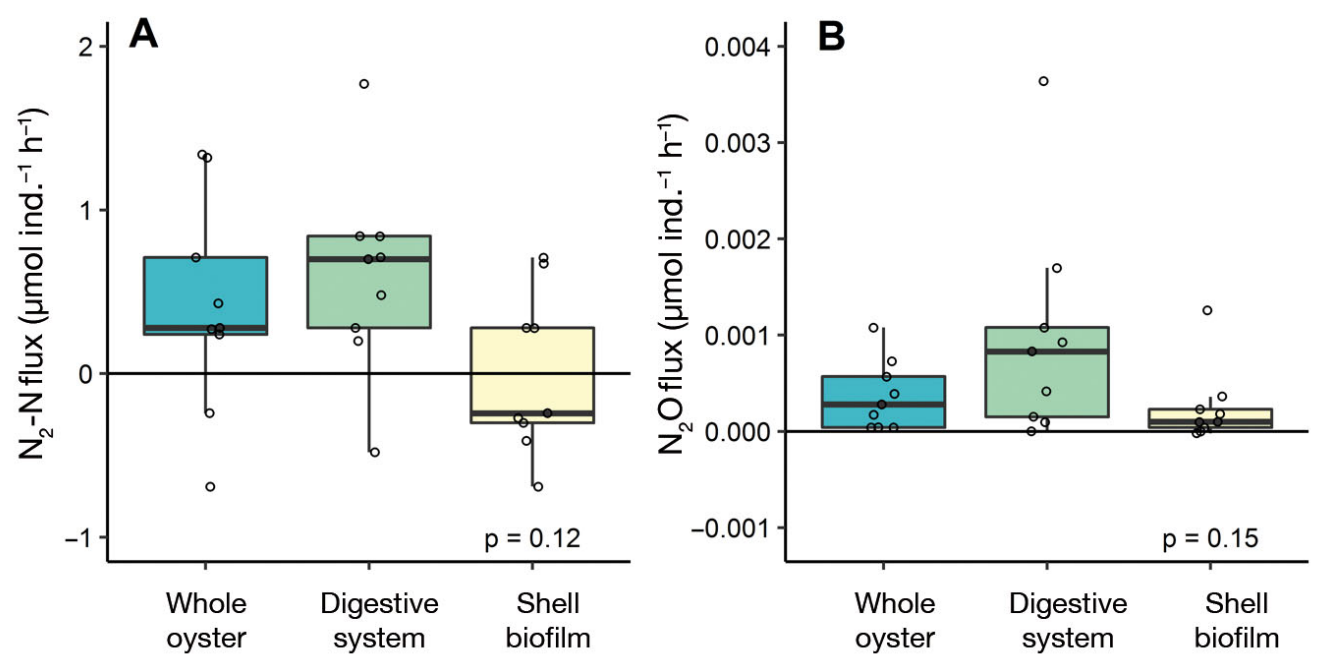

Fig. 3. Fluxes of (A) $\mathrm{N}_{2}-\mathrm{N}$ and (B) $\mathrm{N}_{2} \mathrm{O}$ from whole oysters, the oyster digestive system, and the shell biofilm. Other details as in Fig. 1

cal differences between studies. Smyth et al. (2013) and Arfken et al. (2017) both used flow-through incubations and the $\mathrm{N}_{2} / \mathrm{Ar}$ method to analyze samples, while Caffrey et al. (2016) used both batch and flowthrough experiments, but measured denitrification via the isotope pairing technique (IPT). Oysters in flow-through chambers have exposure to 'new' $\mathrm{NO}_{3}{ }^{-}$ from inflow water, and IPT requires enriching the water with ${ }^{15} \mathrm{NO}_{3}{ }^{-}$in order to acquire a strong signal. In our batch incubations, the only $\mathrm{NO}_{3}{ }^{-}$added to the incubation chamber came from nitrification or from untreated site water that replaced volume lost in the chamber during sample collection.

We predicted that nitrification in the shell biofilm would be exhibited by release of $\mathrm{N}_{2} \mathrm{O}$ and $\mathrm{NO}_{3}{ }^{-}$, and consumption of $\mathrm{NH}_{4}{ }^{+}$. Despite not recording any significant production of $\mathrm{NO}_{3}{ }^{-}$or consumption of $\mathrm{NH}_{4}{ }^{+}$by the biofilm-only treatment, we did find evidence of nitrification. We measured significant release of $\mathrm{N}_{2} \mathrm{O}$ and $\mathrm{NO}_{2}{ }^{-}$, which are a byproduct and intermediate of nitrification, respectively. Additionally, there was high variability in our $\mathrm{NO}_{3}{ }^{-}$flux data (Fig. 2), with some instances of $\mathrm{NO}_{3}{ }^{-}$release, and others of $\mathrm{NO}_{3}{ }^{-}$consumption. This pattern suggests that nitrification was occurring, though at varying rates, and to varying degrees of completion. We expected nitrification to proceed more rapidly in the shell biofilm of whole oysters compared to the shell alone due to $\mathrm{NH}_{4}{ }^{+}$fertilization from the oyster digestive system, yet rates of $\mathrm{N}_{2} \mathrm{O}$ and $\mathrm{NO}_{2}{ }^{-}$release

Table 3. Previously reported rates of denitrification from eastern oysters Crassostrea virginica, and rates recorded in this study

\begin{tabular}{|c|c|c|c|c|c|}
\hline Study & Oyster treatment & Location (USA) & $\begin{array}{l}\text { Incubation } \\
\text { temp. }\left({ }^{\circ} \mathrm{C}\right)\end{array}$ & $\begin{array}{l}\text { Reported denitrifi- } \\
\text { cation rate }\end{array}$ & $\begin{array}{l}\text { Converted denitrifi- } \\
\text { cation rate }\left(\mu \mathrm{mol} \text { ind. }{ }^{-1} \mathrm{~h}^{-1}\right)\end{array}$ \\
\hline Smyth et al. (2013) $)^{a, b}$ & Biofilm removed & Calico Creek, NC & 24.7 & $\sim 500 \mu \mathrm{mol} \mathrm{m}{ }^{-2} \mathrm{~h}^{-1}$ & 1.6 \\
\hline Caffrey et al. $(2016)^{\mathrm{C}}$ & No treatment & Pensacola Bay, FL & 23 & $269 \mathrm{nmol} \mathrm{cm}^{-2} \mathrm{~d}^{-1}$ & 0.82 \\
\hline Caffrey et al. $(2016)^{\mathrm{C}}$ & Shell only & Pensacola Bay, FL & 23 & $74 \mathrm{nmol} \mathrm{cm}{ }^{-2} \mathrm{~d}^{-1}$ & 0.23 \\
\hline Arfken et al. $(2017)^{a}$ & No treatment & Atlantic Beach, NC & 30 & $364.4 \mu \mathrm{mol} \mathrm{m}{ }^{-2} \mathrm{~h}^{-1}$ & 1.17 \\
\hline Arfken et al. $(2017)^{a}$ & Shell only & Atlantic Beach, NC & 30 & $355.3 \mu \mathrm{mol} \mathrm{m}{ }^{-2} \mathrm{~h}^{-1}$ & 1.14 \\
\hline This study & No treatment & Ninigret Pond, RI & 24 & - & 0.41 \\
\hline This study & Biofilm removed & Ninigret Pond, RI & 24 & - & 0.59 \\
\hline This study & Shell only & Ninigret Pond, RI & 24 & - & $0^{\mathrm{d}}$ \\
\hline \multicolumn{6}{|c|}{$\begin{array}{l}{ }^{\text {a }} \text { Smyth et al. }(2013) \text { and Arfken et al. }(2017) \text { both reported denitrification as a function of incubation chamber cross sectional } \\
\text { area }\left(0.0032 \mathrm{~m}^{2}\right) \text {. We converted to a rate per oyster by multiplying by this value } \\
{ }^{\mathrm{b}} \text { The denitrification rate for Smyth et al. }(2013) \text { is estimated from Fig. } 1 \text { in that paper, as the actual value is not reported } \\
{ }^{\mathrm{c}} \text { Caffrey et al. }(2016) \text { reported rates of denitrification per } \mathrm{cm}^{2} \text { oyster shell area. We converted this to denitrification per indi- } \\
\text { vidual by multiplying their reported value by the average oyster shell area in that study }\left(73.52 \mathrm{~cm}^{2}\right) \\
{ }^{\mathrm{d}} \text { The } \mathrm{N}_{2} \text {-N flux for the shell biofilm was not significantly different from } 0(\mathrm{p}=0.50) \text { and is therefore reported as } 0 \text { here }\end{array}$} \\
\hline
\end{tabular}


were not different between whole oysters and the shell biofilm alone, indicating that shell nitrification processes may act in autonomy from digestive processes in Crassostrea virginica. Our results match those reported by Caffrey et al. (2016), who also did not find significant differences in inferred rates of nitrification between whole oysters and empty oyster shells, reporting rates from $0-112 \mathrm{nmol} \mathrm{NO}_{3}{ }^{-}$ $\mathrm{cm}^{-2} \mathrm{~d}^{-1}$. Their reported rate can be converted to 0-0.34 $\mathrm{mmol} \mathrm{NO}_{3}{ }^{-}$ind..$^{-1} \mathrm{~h}^{-1}$, comparable to, but at the lower end of, some rates of $\mathrm{NO}_{3}{ }^{-}$production observed in our study.

Our measured rate of $\mathrm{NH}_{4}{ }^{+}$excretion from whole oysters (12.17 $\mu \mathrm{mol} \mathrm{g}^{-1} \mathrm{~d}^{-1}$, dry tissue weight) falls in the lower range of previously reported rates (11.7$67.39 \mu \mathrm{mol} \mathrm{g}{ }^{-1} \mathrm{~d}^{-1}$; Hammen 1968, 1969, Pietros \& Rice 2003, Ray et al. 2015). We were surprised that the magnitude of $\mathrm{NH}_{4}{ }^{+}$release from the shell biofilm alone was greater than from the digestive system alone. This $\mathrm{NH}_{4}{ }^{+}$efflux suggests that the oyster shell supports a substantial heterotrophic community. It is unlikely that any significant portion of $\mathrm{NH}_{4}{ }^{+}$production was due to dissimilatory nitrate reduction to ammonium (DNRA). Nizzoli et al. (2006) found evidence of DNRA occurring in mussel culture, but were unable to estimate a rate due to 'equivocal' data. Additionally, there are likely low carbon inputs to the shell biofilm, favoring denitrification processes over DNRA (Burgin \& Hamilton 2007).

We measured no difference in $\mathrm{N}_{2}$ - $\mathrm{N}$ production between the oyster digestive system and whole oysters, and greater $\mathrm{NH}_{4}{ }^{+}$from whole oysters compared to just the oyster digestive system. The oyster digestive system and shell biofilm are therefore not stimulating $\mathrm{N}$-cycling processes in each other. Instead, $\mathrm{N}$-cycling processes in each of the 2 oyster microhabitats appear to be uncoupled. On the other hand, whole oysters consumed $\mathrm{O}_{2}$ twice as quickly as the sum of the shell biofilm and digestive system. We consider there to be 2 possible explanations for this pattern: a feedback mechanism between the 2 microhabitats, or increased respiration as a result of higher rates of filter-feeding due to competition for food.

Both the oyster digestive system and shell biofilm released significant quantities of $\mathrm{PO}_{4}{ }^{3}$. The rate we recorded for whole oysters $\left(0.08 \mu \mathrm{mol}\right.$ ind..$\left.^{-1} \mathrm{~h}^{-1}\right)$ and for the oyster digestive system $\left(0.05 \mu \mathrm{mol}\right.$ ind..$\left.^{-1} \mathrm{~h}^{-1}\right)$ were slightly less than the rates reported by Satomi \& Pomeroy (1965) of $0.2 \mu \mathrm{g}$ atoms $\mathrm{P} \mathrm{g}^{-1} \mathrm{~h}^{-1}$ (which converts to $0.28-0.38 \mu \mathrm{mol} \mathrm{PO}_{4}{ }^{3-}$ ind. ${ }^{-1} \mathrm{~h}^{-1}$ when incorporating the spring and summer oyster weights reported in that paper) for whole oysters with the biofilm removed.

\subsection{Ecological implications of $\mathbf{N}$ and $\mathbf{P}$ fluxes from oysters}

The oyster digestive system released both $\mathrm{N}_{2}-\mathrm{N}$ and $\mathrm{NH}_{4}{ }^{+}$, indicating that despite recycling nutrients to the surrounding system, oysters also remove significant quantities of $\mathrm{N}$ from the system. The oysters used in this study had approximately $2.93 \mathrm{~g}$ tissue (dry weight) and took about $2 \mathrm{yr}$ to reach that size. If we assume the tissue is $7.86 \% \mathrm{~N}$ (Higgins et al. 2011), we can estimate that 0.016 moles of $\mathrm{N}$ per oyster are removed from the coastal ecosystem when the oyster is harvested. This value is approximately 2 times greater than the total amount of $\mathrm{N}$ removed through denitrification $(0.007 \mathrm{~mol} \mathrm{~N}$ per oyster) by the oyster digestive system over the same 2 yr time period, even if we assume that the denitrification rate we recorded stays the same regardless of oyster size, and through different seasons and temperature. However, only harvested oysters can remove $\mathrm{N}$ through bio-extraction. In contrast, it is likely that all oysters remove $\mathrm{N}$ through denitrification in their digestive system (Table 3 ). Even oysters that will never be harvested, such as those in restored reefs, or living in polluted waters, will provide this ecosystem service.

While the rate of denitrification for an individual oyster may seem small, oysters typically live or are raised in dense populations. As an example, the farm from which we collected oysters keeps market size oysters ready for sale in densities of at least 250 ind. $\mathrm{m}^{-2}$. Oysters in such a density would yield a removal of $102.5 \mu \mathrm{mol} \mathrm{N} \mathrm{N}_{2} \mathrm{~N} \mathrm{~m}^{-2} \mathrm{~h}^{-1}$ in addition to potentially stimulating denitrification in underlying sediment (Newell et al. 2005, Kellogg et al. 2014). In fact, if oyster aquaculture is to be used as a method to remove excess $\mathrm{N}$ from coastal systems, denitrification occurring in the oyster may be more easily estimated than denitrification in the sediment beneath oyster aquaculture gear. Studies to measure stimulation of sediment denitrification associated with oyster habitats have reported conflicting results, with some studies indicating significant increases in $\mathrm{N}$ removal when oysters are present (Hoellein \& Zarnoch 2015, Smyth et al. 2015, Humphries et al. 2016, Lunstrum et al. 2018) - including a study reporting an average annual increase as high as $460 \mu \mathrm{mol} \mathrm{N} 2-\mathrm{N} \mathrm{m}^{-2} \mathrm{~h}^{-1}$ (Kellogg et al. 2013), while others reported no change (Higgins et al. 2013, Mortazavi et al. 2015, Smyth et al. 2015, Erler et al. 2017). Conversely, each study that has attempted to measure denitrification occurring in or on C. virginica has measured the occurrence of denitrification in a similar range (Table 3). Similarly, Erler et al. (2017) 
In addition to releasing $\mathrm{NH}_{4}{ }^{+}$, oysters release significant quantities of $\mathrm{PO}_{4}{ }^{3-}$ at an $\mathrm{N}: \mathrm{P}$ ratio of 18.4 (using $\mathrm{NH}_{4}{ }^{+}$and $\mathrm{NO}_{2}{ }^{-}$). Oysters do not drive one nutrient to become limiting to primary production, as the ratio of $\mathrm{N}: \mathrm{P}$ excreted by oysters is near the Redfield ratio of $16 \mathrm{~N}: 1 \mathrm{P} . \mathrm{PO}_{4}{ }^{3-}$ release was greater from the shell biofilm than the oyster digestive system, although $\mathrm{PO}_{4}{ }^{3-}$ release from untreated oysters was not statistically different from either the digestive system or the biofilm. Satomi \& Pomeroy (1965) found a strong positive relationship between $\mathrm{PO}_{4}{ }^{3-}$ release and oyster DO consumption, indicating that $\mathrm{PO}_{4}{ }^{3-}$ release is driven by the rate at which oysters are consuming and processing food. As $\mathrm{NH}_{4}{ }^{+}$excretion is also positively correlated with DO consumption in oysters (Boucher \& Boucher-Rodoni 1988), this suggests that $\mathrm{PO}_{4}{ }^{3-}: \mathrm{NH}_{4}{ }^{+}$ in oyster excretions will remain constant regardless of food availability and respiratory rate.

\section{CONCLUSIONS}

In this study, we quantified the magnitude of both inorganic $\mathrm{N}$ and $\mathrm{P}$ fluxes from Crassostrea virginica for the first time and demonstrate how 2 distinct oyster microhabitats regulate these fluxes. The results of our study show that biogeochemical processes in the $2 \mathrm{mi}-$ crohabitats are uncoupled, despite their close physical proximity and distinct redox conditions. We show that denitrification in the oyster digestive system can remove significant quantities of $\mathrm{N}$ from coastal ecosystems, providing an ecosystem service in estuaries with excess anthropogenic $\mathrm{N}$ enrichment. This process proceeds with minimal $\mathrm{N}_{2} \mathrm{O}$ release, contrary to past predictions. While small at the individual oyster scale, when considering large populations of oysters, denitrification occurring in the oyster digestive system proceeds at rates similar to sediment and may provide a more accurate method of estimating oyster-driven $\mathrm{N}$ removal from estuaries than stimulation of sediment denitrification. Additionally, $\mathrm{N}$ remineralized by oysters is released almost exclusively as $\mathrm{NH}_{4}{ }^{+}$, at a ratio of 18.4:1 with P, i.e. relatively close to the Redfield ratio. As oyster and bivalve populations are restored, grow via aquaculture development, or as non-native species are introduced, understanding how different species regulate biogeochemical processes is an important consideration.

Acknowledgements. Funding for this research was made possible by a Rhode Island Sea Grant award to R.W.F., a Boston University Dean's Fellowship and Teaching Fellowship to N.E.R., and a Boston University Undergraduate Research
Opportunities Project award to M.C.H. We thank Jim Arnoux for access to, and information about, his farm; Seth Berger for analyzing nutrient samples on the SEAL; and Alia Al-Haj for assisting with the lab incubations. Parts of this research made up M.C.H.'s senior thesis at Boston University, and we thank the BU Marine Program and her senior thesis committee members Jennifer Bhatnagar and Nathan Stewart.

\section{LITERATURE CITED}

Arfken A, Song B, Bowman JS, Piehler M (2017) Denitrification potential of the eastern oyster microbiome using a 16S rRNA gene based metabolic inference approach. PLOS ONE 12:e0185071

Beaulieu JJ, Tank J, Hamilton SK, Wollheim WM and others (2011) Nitrous oxide emission from denitrification in stream and river networks. Proc Natl Acad Sci USA 108: 214-219

* Beck MW, Brumbaugh RD, Airoldi L, Carranza A and others (2011) Oyster reefs at risk and recommendations for conservation, restoration, and management. Bioscience 61: 107-116

* Bonaglia S, Brüchert V, Callac N, Vicenzi A, Chi Fru E, Nascimento FJA (2017) Methane fluxes from coastal sediments are enhanced by macrofauna. Sci Rep 7:1-10

* Boucher G, Boucher-Rodoni R (1988) In situ measurement of respiratory metabolism and nitrogen fluxes at the interface of oyster beds. Mar Ecol Prog Ser 44:229-238

Burgin AJ, Hamilton SK (2007) Have we overemphasized the role of denitrification in aquatic ecosystems? A review of nitrate removal pathways. Front Ecol Environ 5:89-96

Caffrey JM, Hollibaugh JT, Mortazavi B (2016) Living oysters and their shells as sites of nitrification and denitrification. Mar Pollut Bull 112:86-90

Coen LD, Brumbaugh RD, Bushek D, Grizzle R and others (2007) Ecosystem services related to oyster restoration. Mar Ecol Prog Ser 341:303-307

Colt J (1984) Computation of dissolved gas concentrations in water as functions of temperature, salinity, and pressure. American Fisheries Society Special Publication 14. AFS, Bethesda, MD

Erler DV, Welsh DT, Bennet WW, Meziane T, Hubas C, Nizzoli D, Ferguson AJP (2017) The impact of suspended oyster farming on nitrogen cycling and nitrous oxide production in a sub-tropical Australian estuary. Estuar Coast Shelf Sci 192:117-127

Foster SQ, Fulweiler RW (2014) Spatial and historic variability of benthic nitrogen cycling in an anthropogenically impacted estuary. Front Mar Sci 1:56

Foster SQ, Fulweiler RW (2016) Sediment nitrous oxide fluxes are dominated by uptake in a temperate estuary. Front Mar Sci 3:40

Hammen C (1968) Aminotransferase activities and amino acid excretion of bivalve mollusks and brachiopods. Comp Biochem Physiol 26:697-705

Hammen C (1969) Metabolism of the oyster, Crassostrea virginica. Am Zool 9:309-318

Keisterkamp IM, Schramm A, de Beer D, Stief P (2010) Nitrous oxide production associated with coastal marine invertebrates. Mar Ecol Prog Ser 415:1-9

Heisterkamp IM, Schramm A, Larsen LH, Svenningsen NB, Lavik G, de Beer D, Stief P (2013) Shell biofilm-associated nitrous oxide production in marine molluscs: processes, precursors and relative importance. Environ Microbiol 15:1943-1955 
Higgins CB, Stephenson K, Brown BL (2011) Nutrient bioassimilation capacity of aquacultured oysters: quantification of an ecosystem service. J Environ Qual 40:271-277

*Higgins CB, Tobias C, Piehler MF, Smyth AR, Dame RF, Stephenson K, Brown BL (2013) Effect of aquacultured oyster biodeposition on sediment $\mathrm{N}_{2}$ production in Chesapeake Bay. Mar Ecol Prog Ser 473:7-27

Hoellein TJ, Zarnoch CB (2015) Effect of eastern oysters (Crassostrea virginica) on sediment carbon and nitrogen dynamics in an urban estuary. Estuar Coasts 24: 271-286

Humphries AT, Ayvazian SG, Carey JC, Hancock BT and others (2016) Directly measured denitrification reveals oyster aquaculture and restored oyster reefs remove nitrogen at comparable high rates. Front Mar Sci 3:74

Kana TM, Weiss DL (2004) Comment on 'Comparison of Isotope Pairing and N2:Ar Methods for Measuring Sediment Denitrification' by B. D. Eyre, S. Rysgaard, T. Dalsgaard, and P. Bondo Christensen. 2002. Estuaries 25: 1077-1087. Estuaries 27:173-176

Kana TM, Darkangelo C, Hunt MD, Oldham JB, Bennett GE, Cornwell JC (1994) Membrane inlet mass spectrometer for rapid high-precision determination of $\mathrm{N}_{2}, \mathrm{O}_{2}$, and $\mathrm{Ar}$ in environmental water samples. Anal Chem 66:4166-4170

Kellogg ML, Cornwell JC, Owens MS, Paynter KT (2013) Denitrification and nutrient assimilation on a restored oyster reef. Mar Ecol Prog Ser 480:1-19

Kellogg ML, Smyth AR, Luckenbach MW, Carmichael RH and others (2014) Use of oysters to mitigate eutrophication in coastal waters. Estuar Coast Shelf Sci 151:156-168

King GM, Judd C, Kuske CR, Smith C (2012) Analysis of stomach and gut microbiomes of the eastern oyster (Crassostrea virginica) from coastal Louisiana, USA. PLOS ONE 7:e51475

Lacoste E, Gaertner-Mazouni N (2015) Biofouling impact on production and ecosystem functioning: a review for bivalve aquaculture. Rev Aquacult 7:187-196

* Lunstrum A, McGlathery K, Smyth A (2018) Oyster (Crassostrea virginica) aquaculture shifts sediment nitrogen processes toward mineralization over denitrification. Estuaries Coasts 41:1130-1146

Mortazavi B, Ortmann AC, Wang L, Bernard RJ and others (2015) Evaluating the impact of oyster (Crassostrea virginica) gardening on sediment nitrogen cycling in a subtropical estuary. Bull Mar Sci 91:323-341

Myhre G, Shindell D, Breon FM, Collins W and others (2013) Anthropogenic and natural radiative forcing. In: Stockner TF, Qin D, Plattner GK, Tignor M and others (eds) Climate change 2013: the physical science basis. Contribution of Working Group 1 to the Fifth Assessment Report of the Intergovernmental Panel on Climate Change. Cambridge University Press, Cambridge, p 659-740

Newell RIE (1988) Ecological changes in Chesapeake Bay: Are they the result of overharvesting the American oyster, Crassostrea virginica? In: Understanding the estuary: advances in Chesapeake Bay Research. US EPA CBP/ TRS 24/88. CRC Publication 129. Chesapeake Bay Consortium, Solomons, MD, p 536-546

Newell R, Fisher T, Holyoke R, Cornwell J (2005) Influence of eastern oysters on nitrogen and phosphorus regeneration in Chesapeake Bay, USA. In: Dame RF, Olenin S (eds) The comparative roles of suspension-feeders in ecosystems. Springer, Dordrecht, p 93-120

Nizzoli D, Welsh DT, Fano EA, Viaroli P (2006) Impact of clam and mussel farming on benthic metabolism and nitrogen cycling, with emphasis on nitrate reduction pathways. Mar Ecol Prog Ser 315:151-165
Nocker A, Lepo JE, Snyder RA (2004) Influence of an oyster reef on development of the microbial heterotrophic community of an estuarine biofilm. Microbiology 70 : 6834-6845

* Peterson $\mathrm{CH}$, Grabowski JH, Powers SP (2003) Estimated enhancement of fish production resulting from restoring oyster reef habitat: quantitative valuation. Mar Ecol Prog Ser 264:249-264

Pietros JM, Rice MA (2003) The impacts of aquacultured oysters, Crassostrea virginica (Gmelin, 1791) on water column nitrogen and sedimentation: results of a mesocosm study. Aquaculture 220:407-422

Prairie YT (1996) Evaluating the predictive power of regression models. Can J Fish Aquat Sci 53:490-492

R Core Team (2014) R: a language for statistical computing. R Foundation for Statistical Computing, Vienna

Ray NE, Li J, Kangas PC, Terlizzi DE (2015) Water quality upstream and downstream of a commercial oyster aquaculture facility in Chesapeake Bay, USA. Aquacult Eng 68:35-42

Satomi M, Pomeroy LR (1965) Respiration and phosphorus excretion in some marine populations. Ecology 46: 877-881

* Seitzinger SP, Nixon SW (1985) Eutrophication and the rate of denitrification and $\mathrm{N}_{2} \mathrm{O}$ production in coastal marine sediments. Limnol Oceanogr 30:1332-1339

* Smyth AR, Thompson SP, Siporin KN, Gardner WS, McCarthy MJ, Piehler MF (2013) Assessing nitrogen dynamics throughout the estuarine landscape. Estuaries Coasts 36:44-55

* Smyth AR, Piehler MF, Grabowski JH (2015) Habitat context influences nitrogen removal by restored oyster reefs. J Appl Ecol 52:716-725

Stief P (2013) Stimulation of microbial nitrogen cycling in aquatic ecosystems by benthic macrofauna: mechanisms and environmental implications. Biogeosciences 10: 7829-7846

Stief P, Poulsen M, Nielsen LP, Brix H, Schramm A (2009) Nitrous oxide emission by aquatic macrofauna. Proc Natl Acad Sci USA 106:4296-4300

* Svenningsen NB, Heisterkamp IM, Sigby-Clausen M, Larsen LH, Nielsen LP, Stief P, Schramm A (2012) Shell biofilm nitrification and gut denitrification contribute to emission of nitrous oxide by the invasive freshwater mussel Dreissena polymorpha (zebra mussel). Appl Environ Microbiol 78:4505-4509

* Tamburri MN, Zimmer-Faust RK, Tamplin ML (1992) Natural sources and properties of chemical inducers mediating settlement of oyster larvae: a re-examination. Biol Bull (Woods Hole) 183:327-338

*Wahl M, Goecke F, Labes A, Dobretsov S, Weinberger F (2012) The second skin: ecological role of epibiotic biofilms on marine organisms. Front Microbiol 3:1-21

*Weiss RF (1970) The solubility of nitrogen, oxygen and argon in water and seawater. Deep-Sea Res Oceanogr Abstr 17:721-735

Welsh DT, Castadelli G (2004) Bacterial nitrification activity directly associated with isolated benthic marine animals. Mar Biol 144:1029-1037

WWelsh DT, Nizzoli D, Fano EA, Viaroli P (2015) Direct contribution of clams (Ruditapes philippinarum) to benthic fluxes, nitrification, denitrification and nitrous oxide emission in a farmed sediment. Estuar Coast Shelf Sci 154:84-93

Zu Ermgassen PSE, Spalding MD, Blake B, Coen LD and others (2012) Historical ecology with real numbers: past and present extent and biomass of an imperilled estuarine habitat. Proc R Soc B 279:3393-3400 